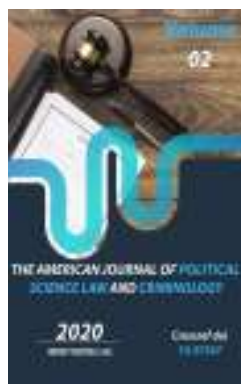

\title{
The Organisation Of Islamic Cooperation And Arab World: Processes Of Events
}

\author{
Quysinova Fazilat Oripovna \\ PhD Student, Uzbekistan State World Languages University, Uzbekistan
}

Journal Website: http://usajournalshub.c om/index,php/tajpslc

Copyright: Original content from this work may be used under the terms of the creative commons attributes 4.0 licence.

\section{ABSTRACT}

The article highlights the activities of the Organization of the Islamic Conference for the consolidation of Arab states. In the context of international relations in the Middle East region, political problems in the Arab world are analyzed and a brief classification of conflicts in the Middle East in the XX century is given. Also studied the image of the Organization of the Islamic Conference in international relations.

\section{KEYWORDS}

Geopolitics, international relations, international organizations, solidarity, the political life of the world.

\section{INTRODUCTION}

At present, characterized by the constant transformation of modern world politics, with a higher increase in the role and the status of countries, the international structures are highly surged as well. The fact that the impact of these structures on the processes that are taking place is inexhaustible also manifests itself as a specific trend of the political life of the world.

One of the most important factors of modern international relations is international organizations, and today many of them are of particular importance with the potential to have a direct impact on international politics. In 
addition to the fact that in the foreign policy of our country, the attention is paid to the development of cooperation with the world community and international structures in the system of international relations, the connections with many Muslim countries, which are culturally close, it is necessary to recognize that now more than fifty international organizations are equal members. Among them, the growing prestige in the international arena draws special attention to the development of relations with the Organization of Islamic Cooperation. It can also be noted that Uzbekistan views the Organization of Islamic Cooperation as a universally recognized forum uniting Muslim countries, which is an important direction of modern foreign policy [1].

\section{MATERIALS AND METHODS}

The political platform of the Organization of Islamic Cooperation (the name of the Organization of Islamic Conference was changed to the Organization of Islamic Cooperation at the 38th session of foreign ministers held in Astana on June 28, 2011), which united the Muslim world around itself in political and cultural terms, is the largest international organization that ranks after the UN. In the second half of the last century, the complexity of world politics, the constant and dynamic changes in international relations were an object of the organization's existence. Although, on August 21, 1969, the fire at Masjid Al-Aqsa [2] shocked Muslim nations all over the world and this situation was the basis of the unification of several Muslim countries on a global scale and the call for a separate conference, as a result of which the Organization of the Islamic Conference was formed. In fact, the emergence of an organization was a ripening issue of those times. At a time when only one Turkish is needed for the political unification of the
Muslim world, and the incident with Jerusalem will serve as such a Turk.

Another main reason is the fact that Muslim countries are experiencing colonialism as third world countries, in all respects, it has fallen under the influence of Western countries, the continuation of both economic and political dependence on them, the most important thing is that the fate of the main part of Muslim countries remains in the hands of European countries and governments.

The Middle East region was a permanent centre of the intersection of the interests of many countries, certain forces, groups, transnational corporations. Therefore, the fact that its richness in energy resources, the calculation of the cradle of ancient civilization, has not always brought happiness and prosperity to the countries located in these territories, has found evidence of many times in history. In the geopolitical struggle, the region has become one of the most affected regions. This is happening both in history and today, although, regardless of belonging to different races, nationalities, on which territory they reside, the Muslim countries do not lag behind the development of the world in the second half of the 2oth century, their desire to restore their glorious history as free and independent states increases. This factor, that is, the perception of the glorious past, the sense of belonging to the ancestors, the desire of powerful states to leave the colonial policy and become free, the feeling of self-exclusion from the ranks of "oppressed and humiliated" nations, the way of uniting Islamic states, in what format the way of achieving integration was considered very important.

"The idea of uniting Muslims from all over the world through the establishment of an international organization came into being among the world figures in Palestine after the 
First World War. Such an idea was put forward by Sheikh Mohammed Amin Al-Hosseini, a Jerusalem scholar, among the first" [3:]. Of course, the establishment of the Arab states, the integration of the Arab states, has historically been carried out within the framework of various organizations. Among them, it should be noted the activities of the League of Arab states (League of Arab states), the organization of Arab Petroleum exporting countries (Organization of Arab Petroleum exporting countries), The Cooperation Council for the Arab states of Gulf) and several other organizations that have made great efforts to further develop the integration processes in the Middle East region. But the activities of such organizations did not always yield results. Although there is wide coverage in the activities of organizations, the main causes of inefficiency, the aspirations and rivalry of the countries of the region towards leadership, the lack of interest of external forces from the unification of Muslim states, the constant influence, as well as the interests of the Islamic world were also in the variety.

Factors such as the extreme processes that took place in the second half of the last century, namely the Arab-Israeli wars, the invasion of Jerusalem by Israel and the expulsion of many Palestinians from their lands, led to a complete change in the situation. It is said that if the Arab countries of the Middle East had put a broad emphasis on the policy of supremacy, now they are united on the basis of solidarity, the factors of the fight against common danger began to call for unity. The policy of mutual disagreement between Arab countries in relation to each other began to be eradicated. Countries such as Egypt and Syria, which have an unusually high position in the Arab world, have now worked towards cooperation with Saudi Arabia. These realities meant that the period of unification and solidarity of the countries of the Middle East began.

Saudi King Faisal's initiatives to hold a conference of the supreme leaders of Islamic countries have now begun to open the way. As a result, on August 25, 1969, a month before the establishment of the OIC, a meeting of foreign ministers of 14 Arab states was held in the city of Cairo. At this meeting, Saudi Arabia's initiative call for Islamic Conference was unanimously supported. It should be noted that the basis of the organization of the OIC on September 25, 1969, was the increasing need of many independent Muslim countries for solidarity and the desire to jointly protect and preserve sacred cities, feelings for Muslims [4:]. The prestige of the new organization that came into existence was that it was not only Muslim Arab countries but also other countries whose population was determined to follow the religion of Islam.

The political basis of the organization of the Islamic Conference is the preservation of national sovereign states, prioritizing Islamic Solidarity [5]. Although it may be repeated, the Organization of the Islamic Conference is not an organization that emerged unintentionally, carries out short-term tactical tasks, but an organization whose time has been set its need and this need has increased relying on many causes and political factors. Islamic Solidarity in the organization is the most basic ideology and is also viewed by the heads of state and government as a priority way of achieving Islamic Development. The main motivation that unites Muslim countries is the fight against colonialism and the preservation of Islamic values, lifestyle, sacred factors, these factors are reflected in the software documentation of the organization. 
There are specific political bases and factors for the organization of the Islamic Conference, which are reflected as followings:

- The growing desire of the Arab countries of the Middle East to unite as a result of experiencing many painful days;

- Although the views among the governments are different, the Palestinian people seek to unite on the basis of solidarity with the aim of saving them from oppression, which in itself is the basis of the integration of the Arab people;

- The need to take serious steps to solve the Israeli-Palestinian problem, especially the need to return the persecuted Palestinians to their lands and protect the holy mosque for Muslims is understood;

- The need to protect national and religious interests in the conditions of increasingly geopolitical struggles and conflicts in the region;

- Gradually beginning to realize that disproportionate foreign policy is extremely dangerous for the life of the region;

- The political, economic, military, financial and most important spiritual potential for the formation of an International Organization of all Muslims and the Middle Eastern States was fully formed.

In general, the Organization of the Islamic Conference began to play an important role in world politics as an organization that unites different procedures and countries. The main thing is that the organization, together with its leading Arab countries, also covers the dreams and aspirations of African countries, deserves special attention. Only the Organization of the Islamic Conference, which united Muslim countries in spite of their denominations, race, political views, economic differentiation, has been manifested as an organization that embodies the long-standing aspirations of the Islamic people.

In the early years of its ICT activities, its work was distinguished by the fact that its effectiveness covered in-depth strategic goals, was based on the protection of the interests of the Muslim world, as well as a high level of political activity. Because the goals were still new, and all member states were determined by a new approach (enthusiasm) to the structure of the organization and its subsequent activities. But many factors, such as the internal and external complexities encountered in the process of the activities of the organization, the great international pressure of the member states, the difficult nature of the implementation of the tasks set out in the programming documents, the fragility of views, the unevenness in the development of the member states of the organization, the constant conflict of interests.

Since the establishment of ICT, two different trends have been formed among the member states of the organization. The first trend is a cooperation between states. The basis for our cooperation is that not only Arab countries, but also all Muslim countries want to cooperate, support Palestine, unite for the reputation and status of the Muslim world.

The second trend-competition between these countries, that is, the escalation of competition was manifested in the fact that in these processes. There was an increase in the ranks of states seeking to conduct their own judgment, to ensure leadership, to more closely integrate their will within the organization. Naturally, countries such as Saudi Arabia, Iran, Turkey, Pakistan, Egypt were encouraged to join the ranks of these countries. It became increasingly clear that each of them did not abandon the desire to turn the Organization of the Islamic 
Conference into the most important tool for strengthening its foreign policy and position.

Also, if we comment on our thoughts about the different foreign policy course of the member countries:

- Although the main goal is to fight against Israeli aggression, sympathize with the Palestinians, protect the interests of the Islamic people, the organization's member states have different political positions on Israel;

- The existence of a different approach to political processes in foreign policy issues and lack of continuity;

- The emergence of a variety of relations between the United States, the former Soviet Union, France and Great Britain in relation to their foreign political activities, which they carried out to attract the countries of the region to their sphere of influence, etc.

For example, in the case of the establishment of Israel and its occupation of Palestinian lands, Arab and Muslim populations in the early years have been extreme, this situation has softened for some time over the past period. Some Arab and Muslim countries have so far established even diplomatic relations with Israel, and these processes gradually involve other Arab and Muslim countries.

The sharp increase in demand for energy resources in harmony with the development of the world further strengthened the capabilities of Arab monarchies. With very large financial resources, the Arab countries that have the power to have a direct impact on the lives of the Middle East in any way, even within the framework of the Organization of the Islamic Conference in order to strengthen their political position in the region, have also begun to strive for leadership
From the disagreements and constant struggles between the two religiousideological currents - Shiite and Sunni-in Saudi Arabia and Iran, the Organization of the Islamic Conference suffered a lot. Both countries tried to more closely integrate their views on the programming documents and goals of the organization. As the main reason for their right to such a status, they tried to base themselves on the high level of sponsorship and membership contributions they had allocated for the Organization of the Islamic Conference, along with the financial, humanitarian and social assistance they had been providing to the Muslim world, as well as to the pioneering countries. As we have already said, Saudi Arabia is one of the largest donors of the Organization of the Islamic Conference.

Also, factors such as the constant rivalry of the two poles of the former Soviet Union and the United States, which at that time determined the world politics, their interference in the life of the region, their geopolitical struggle, their attempts to artificially inflame processes in the Middle East, the emergence of disagreements, as well as the efforts to bring the states The two poles, which split up the Middle East, have been pursuing their policies in the region, and this situation, in turn, has been a serious obstacle to the implementation of the programming goals that the organization must implement into life.

When talking about the political views of the organization of the Islamic Conference or its internal political situation, it is worth noting that the members of the organization were victims of politics inherent in that period. It is known that the members of the organization belong to the categories of developing countries, the development in them, the economic, social and political situation was also different. Ensuring the independence and sovereignty of the OIC in the international 
arena has become one of the most pressing issues. Because of the constant efforts to undermine the philanthropy of Arab countries and Muslim countries, ideological opposition, have dealt a huge blow to the programming goals.

Analyzing the political effectiveness of the organization of the Islamic Conference in 19691990 years, it can be said that the Middle East countries, which had been developing and searching their own economic life, experiencing great damage from various urges and conflicts, would have experienced a real exam. But the issues of elimination of economic backwardness, active participation in international economic relations and the transition to a technical and technological renewal were, to the extent possible, tied the member-states of the organization to the Western countries. Logically, this situation, on the one hand, had established a very large connection with the activities of the organization, on the other hand, with the life of the member countries. In this case, several decisions were made and introduced into life by the organization.

In the course of its activities, the organization has not been able to carry out a peacekeeping mission due to the lack of a clear mandate in this regard, the potential for the application of strict prohibitions, although it has tried to stop, prevent, resolve conflicts between different groups in Lebanon, long-term bloody wars between Iraq and Iran, the fighting between Iraq and Kuwait, In some cases, initiatives of some member states or the United Nations, and not of the organization, have taken a special place in the achievement of peace.

The emergence of new states on the world map at the end of the XX century directly began a new era in the ICT foil. The adoption of Uzbekistan, Kazakhstan, Kyrgyzstan,
Azerbaijan and other countries in the ranks of members further expanded the range of activities of the organization. The member states of the OIC belong to three groups: - Arab countries rich in influential oil; - Central Asia and some European countries; - non-developed African countries are included. While the increase in the number of Member States brings the issue of solving new problems and solutions to the organization in its turn, it is precisely that the OIC works to unite the member states that are against each other in terms of interests and to maintain stability in the Muslim world in the light of their solidarity. ICT became the basis for Integration, Alliance and cooperation not only between the Arab countries of the Middle East but also among all Muslim countries. American scientists. According to Huntington, "there is no stateowned organizations established on religious grounds in the Orthodox, Buddhist and Jewish states, while for Muslim governments there is such an organization" [6] - This is the Organization of the Islamic Conference.

IHT is considered as a platform of merit, through which stakeholders can establish cooperation on economic, cultural and other issues [7], and is now an important political and legal phenomenon not only in Islam but also in the development of the world as a whole. Factors that have a positive impact on the activities of the Organization of Islamic Cooperation:

- Religious (Islam) unity of the member states of the organization.

- Possession of strategically important raw materials reserves of the member states of the organization;

- Significant resources that affect the economy of Western countries (oil, gas, etc.)

- $\quad$ The fact that the IHT covers a large territory is also a member of powerful 
states that have their place in the modern international arena.

Also, changes in the geopolitical situation did not bypass the OIC, new ones came into being, demographic changes in the Muslim world, mass migration, the politicization of Islam, socio-economic problems on the old problems that did not find their solution during the activities of the organization. These problems have now become a global political problem, not just the IHT or the member states themselves.

Although the leadership level of the IHT is high, it is difficult to prevent and eliminate the risks and threats that arise. Due to this, the organization is faced with the question of how these problems and conflicts can be eliminated, and the question of whether to establish or reorganize the next vector of development of the organization has been raised in many ways. Because, the issue of reformation is very important for the International Organization, which was formed in the previous captives, and which reflected the purpose and function of international relations at that time.

In order to further increase the effectiveness of the IHT activity, step-by-step reforms have been carried out since the establishment of the organization. For example, the amendments to the Charter of the OIC, the improvement of its activities, the reorganization of the name of the organization, the establishment of Secretariat powers, the introduction of the commission for the protection of human rights, the development of a system of control over the mandatory payment of contributions by member states, modernization of the organization are in the sentence [8].

How to transform the Organization of Islamic Cooperation and how these reforms will benefit in solving the problems can be arisen. We can interpret these thoughts as follows:

Because of the conflicts that arose in the Islamic world and the problems that are not being solved within the organization, the transformation itself is not enough to improve the efficiency of the Organization of Islamic Cooperation. Because every organization has its priorities and interests of its members and this does not correspond to the interests of other participants in the organization.

\section{CONCLUSION}

In summary, we can say that the factors that negatively affect the activities of the Organization of Islamic Cooperation:

- Although the leadership level of the organization of Islamic Cooperation as the largest organization of the entire Muslims is high in the international arena, in many cases other organizations are leading the solution of political problems in the Muslim world;

- Because of the structure of various organizations and the inefficiency of their activities, confidence in international organizations in all states has been undermined, the Organization of the Islamic Conference has been established and many problems that could not be solved by previous international organizations have been inherited by it;

- Conflict of national and strategic interests of the participating states;

- Reckon with the interests of the leading countries leads to the weakening of the activities of the OIC as a whole, a single regional structure;

- The territorial location of the OIC member states on different continents of the world. 
Doi: https://doi.org/10.37547/tajpslc/Volume02Issue11-06

\section{REFERENCES}

1. UZA. (2016, October 20). Address by Acting President of the Republic of Uzbekistan H.E. Mr. Shavkat Mirziyoyev at the opening ceremony of the 43rd session of the Council of Foreign Ministers of the Organization of Islamic Cooperation. http://uza.uz/en/posts/address-byacting-president-of-the-republic-ofuzbekistan-h--20-10-2016.

2. uzbekistan.lv. (2018, July 25). O'zbekiston Respublikasi Tashqi ishlar vazirligi rahbari Islom hamkorlik tashkiloti Bosh kotibini qabul qildi. https://uzbekistan.Iv/uz/ozbekistonrespublikasi-tashqi-ishlar-vazirligirahbari-islom-hamkorlik-tashkilotibosh-kotibini-qabul-qildi/

3. Aljazeera. (2018, August 9). History of Masjid Al Aqsa :The Reason of Conflict. Islam Hashtag. https://islamhashtag.com/history-ofmasjid-al-aqsa-the-reason-of-conflict/

4. Sh.Yovqochev. (2016). The Islamic factor in world politics. [S Yovkochev. (2016). Islam as a factor in world politics. Tashkent. p.176.]File of Islamic Summit Conference and Islamic Conferences of Foreign Ministers. Riyadh: Saudi Press Agency. 1989, 434 p.

5. Resolution no.28/28-p On The security and solidarity of Islamic States Republic of Mali 25-27 June 2001.

6. Huntington, S. (2003). Clash of Civilizations lane. from English $\mathrm{T}$. Velemeeva, Yu. Novikova.

7. Organisation of Islamic Cooperation. (n.d.). Www.Oic-Oci.Org. Retrieved November 19, 2020, from https://www.oic-oci.org/

8. http://www.oic-

oci.org/is11/english/Charter-en.pdf;
9. http://www.oic-oci.org/exsummit/english/10-years-plan.htm;

10. http://www.oicoci.org/baku2006/english/documents. htm 